\title{
Involvement of KLF14 and egr-1 in the TGF-beta1 action on Leydig cell proliferation
}

\author{
C.R. Gonzalez ${ }^{\text {a }}$, S.S. Vallcaneras ${ }^{\text {b }}$, R.S. Calandra ${ }^{\text {c }}$, S.I. Gonzalez Calvar ${ }^{\text {c,d, }, *}$ \\ ${ }^{a}$ Research Center of Biomedical Biotechnology, Environmental and Diagnostic Studies, Maimónides University, Hidalgo 775, 1405 Buenos Aires, Argentina \\ ${ }^{\mathrm{b}}$ Laboratory of Biology of Reproduction, School of Chemistry, Biochemistry and Pharmacy, National University of San Luis, Ejército de los Andes 950, 5700 San Luis, Argentina \\ ${ }^{\mathrm{c}}$ Institute of Biology and Experimental Medicine, National Council for Scientific and Technical Research, Vuelta de Obligado 2490,1428 Buenos Aires, Argentina \\ ${ }^{\mathrm{d}}$ School of Medicine, Buenos Aires University, Paraguay 2155, 1121 Buenos Aires, Argentina
}

\section{A R T I C L E I N F O}

\section{Article history:}

Received 6 September 2012

Received in revised form 28 November 2012

Accepted 7 December 2012

Available online 11 January 2013

\section{Keywords:}

TGF- $\beta 1$

Leydig cells

Proliferation

KLF14

\begin{abstract}
A B S T R A C T
Transforming growth factor $\beta 1$ (TGF- $\beta 1$ ) is a pleiotropic cytokine that modulates cell homeostasis. In Leydig cells, TGF- $\beta 1$ exerts stimulatory and inhibitory effect depending on the type I receptor involved in the signaling pathway. The aim of the present work was to study the signaling mechanisms and the intermediates involved in the action of TGF- $\beta 1$ on TM3 Leydig cell proliferation in the presence or absence of progesterone.

The MTT assay showed that the presence of progesterone in the culture media lead to a proliferative effect that was blocked by Ru 486, an inhibitor of progesterone receptor; and ALK-5 did not participate in this effect.

TGF- $\beta 1(1 \mathrm{ng} / \mathrm{ml}$ ) increased the expression of p15 (an inhibitor of cell cycle) in TM3 Leydig cells, and this effect was blocked by progesterone $(1 \mu \mathrm{M})$. The expression of PCNA presented a higher increase in the cell cultured with TGF- $\beta 1$ plus progesterone than in cells cultured only with TGF- $\beta 1$.

Progesterone induced the gene expression of endoglin, a cofactor of TGF- $\beta 1$ receptor that leads to a stimulatory signaling pathway, despite of the absence of progesterone response element in endoglin gene. In addition, the presence of progesterone induced the gene expression of egr- 1 and also KLF14, indicating that this steroid channels the signaling pathway into a non-canonical mechanism. In conclusion, these findings suggest that the proliferative action of TGF- $\beta 1$ involves endoglin. This co-receptor might be induced by KLF14 which is probably activated by progesterone.
\end{abstract}

(C) 2012 Elsevier Ltd. All rights reserved.

\section{Introduction}

From the characterization of the transforming growth factor (TGF- $\beta$ ) family, numerous actions of TGF- $\beta$ have been described including differentiation, proliferation, apoptosis, migration, wound healing, immune system regulation and extracellular matrix production [1]. In the testis, particularly, it was observed that TGF- $\beta 1$ regulates its functionality [2], development [3], inhibits steroidogenesis [4], modulates the contractility of peritubular cells [5], controls the proliferative activity of progenitor cells of Leydig cells [6], stimulates apoptosis of germ cells [7], and promotes the maturation of Leydig cell morphology by enhancing the production of extra cellular matrix protein [8].

TGF- $\beta 1$ inhibitory and stimulatory properties have been described in the regulation of cellular homeostasis in both

\footnotetext{
* Corresponding author at: Institute of Biology and Experimental Medicine, National Council for Scientific and Technical Research, Vuelta de Obligado 2490, 1428 Buenos Aires, Argentina. Tel.: +54 11783 2869; fax: +54 1147862564 .

E-mail addresses: gonzalez.candela@maimonides.edu (C.R. Gonzalez),ssvallca@ unsl.edu.ar (S.S. Vallcaneras), ricardoscalandra@gmail.com (R.S. Calandra), gonsicalvar@yahoo.com, gonsi@fmed.uba.ar (S.I. Gonzalez Calvar).
}

physiological and pathological stages [1]. Lebrin et al. [9] have described that low doses of TGF- $\beta 1$ stimulate epithelial cell proliferation, whereas high doses inhibit this response in vitro.

This plethora of actions lead us to assume that the mechanism involved in the action of TGF- $\beta 1$ depends on the presence of various factors that constitute the cellular environment in which are immersed Leydig cells.

The effects of TGF- $\beta 1$ are exerted, in different tissues, via specific type I and type II serine/threonine kinase receptors. Type II receptor (TGFBRII) transphosphorylates and activates type I receptor (TGFBRI). It has been described two TGFBRI: activin receptorlike kinase 1 (ALK-1), which signals via phosphorylation of Smads $1 / 5$, and activin receptor-like kinase 5 (ALK-5), which signals via phosphorylation of Smads 2/3 [10]. Besides these intracellular mechanisms involving Smad proteins (namely canonical mechanism) TGF- $\beta 1$ exerts its action via non-smads proteins and mitogen-activated protein kinases (MAPKs), particularly ERK $1 / 2$ and p38 (namely non-canonical mechanism) [11].

The factors that drive signaling to ALK-1/ALK-5 or to canonical/ non-canonical mechanism in different tissues are not clearly defined. In this context, endoglin appears to be a key co-receptor that inhibits the ALK-5 signaling pathway resulting in an efficient 
transduction pathway of ALK-1 [9]. Goumans et al. [12] have reported that ALK-1 is an antagonist of Smad 2/3 activation facilitating TGF- $31 / A L K-5$ signaling. Xu et al. [13] have pointed out that the intricate regulation of TGF- $\beta$ receptors and proteins associated in their signaling pathway determine the TGF- $\beta$ responsiveness of the cell.

Recently, it has been described that TGF- $\beta 1$ can regulate the expression of transcription factors, such as early growth response factor-1 (egr-1) and Krüppel-like factor 14 (KLF14). Both factors are characterized by the presence of zinc finger domains responsible for DNA binding and regulation of the transcription of various genes. In this context, Hou et al. [14] have reported that TGF- $\beta 1$ is able to induce a rapid and transient accumulation of egr-1 protein and mRNA in human skin fibroblasts. Previous studies have implicated egr-1 in cell growth, differentiation, and survival. On the other hand, KLF14 is a transcription factor characterized by the presence of three highly conserved C-terminal Cys2His2 zinc finger domains responsible for DNA binding and regulates the transcription of various genes. It has been shown that KLF14 is an important non-smad protein up-regulated upon TGF- $\beta$ treatment that efficiently represses the TGFBRII [15].

To our knowledge, reports concerning TGF- $\beta$ action on Leydig cell proliferation are scarce. Recently we have demonstrated that TGF- $\beta 1$, in the presence of progesterone, enhance the expression of the co-receptor endoglin, and induces Smad 1/5 phosphorylation and PCNA expression in purified Leydig cells from immature mice. Furthermore, the in vivo treatment with TGF- $\beta 1$ (intratesticular) plus progesterone (s.c.) increases the volume of Leydig cells indicating a clear effect of TGF- $\beta 1$ in the hypertrophy/hyperplasia of Leydig cells [16]. On the other hand, we have described a clear correlation between ALK-1 and endoglin gene expression in human testes with Hypoespermatogenesis and Sertoli Cell Only Syndrome which present Leydig cell hyperplasia [17].

It has long been described that, in different cell types, TGF- $\beta 1$ presents not only proliferative effect but also inhibitory effect. Previously, we have reported that TGF- $\beta 1$ induces the expression of $\mathrm{p} 15$, leading to a quiescent stage of Leydig cells [18].

The cellular line TM3 was developed from non-tumoral Leydig cells of immature mouse testis (BALB/c strain). This cell line responds to $\mathrm{LH}$ secreting testosterone, and to different stimulating factors modifying cellular proliferation [19]. Therefore, these features make the TM3 cell line in an experimental model particularly useful in studying various aspects related to the functionality of Leydig cells.

The aim of the present work was to study the signaling mechanisms and the intermediary factors involved in the action of TGF$\beta 1$ on TM3 Leydig cell proliferation in the presence or absence of progesterone.

\section{Materials and methods}

\subsection{TM3 cell line}

TM3 cell line (American Type Culture Collection, USA), derived from immature mouse Leydig cells, were cultured in F12-DME medium (pH 7.2; Sigma, St. Louis, MO, USA) supplemented with $5 \%$ horse serum and $2.5 \%$ fetal calf serum ( 7000 cells $/ \mathrm{cm}^{2}$ ). The cells were kept at $37^{\circ} \mathrm{C}$ in humidified atmosphere containing air and carbon dioxide (95\%/5\% vol/vol). The cells were synchronized by culturing cells for $24 \mathrm{~h}$ in free-serum media and in serum reduced medium (2.5\% horse serum, $1 \%$ fetal calf serum) for another $24 \mathrm{~h}$. Before the stimulus, cells were incubated with free-serum media for $1 \mathrm{~h}$.

\subsection{In vitro incubations of TM3 with TGF-beta 1}

Petri dishes containing synchronized cells were incubated in the presence or absence of TGF- $\beta 1$ (Sigma, St. Louis, MO, USA;
$1 \mathrm{ng} / \mathrm{ml}$ ); or TGF- $\beta 1$ plus Progesterone (Sigma, St. Louis, MO, USA $1 \mu \mathrm{M})$. The incubation period ranged from 5 to $60 \mathrm{~min}(5,10,15$, 30 and $60 \mathrm{~min}$ ). After incubation, the media were removed, and cells were harvested and kept at $-80^{\circ} \mathrm{C}$ until RNA extraction.

\subsection{RNA isolation and semi-quantitative and quantitative $P C R$}

Total RNA from TM3 Leydig cells was extracted with the RNA easy kit (Qiagen Inc., Valencia, MO, USA) according to the manufacturer's instructions. Total RNA $(0.4 \mu \mathrm{g})$ was treated with DNAsel (Invitrogen, Life Technologies, Carlsbad, CA, USA) and used (20 l) for reverse transcription reaction using M-MLV reverse transcriptase (200 U/ $\mu$ l, Promega, Madison, USA) and random hexamer primers (Biodynamics, Buenos Aires, Argentina).

Reverse-transcribed cDNAs $(5 \mu \mathrm{l})$ were used to amplify mRNA sequences by a semi-quantitative PCR reaction with Go-TaqDNA polymerase (Promega, Madison, USA) and specific forward and reverse primers (Table 1 ).

The first denaturation was performed for $4 \mathrm{~min}$ at $94{ }^{\circ} \mathrm{C}$. The successive denaturation steps were performed for $1 \mathrm{~min}$ at $94{ }^{\circ} \mathrm{C}$ followed by annealing at specific temperature (Table 1 ) for $1 \mathrm{~min}$ and extension at $72{ }^{\circ} \mathrm{C}$ for $90 \mathrm{~s}$. A number of cycles were used for each pair of primers (Table 1). A final elongation for $7 \mathrm{~min}$ at $72{ }^{\circ} \mathrm{C}$ was used to amplify transcripts. The amplified cDNA fragments were size-fractionated in $2 \%$ agarose gel and visualized by staining with ethidium bromide.

For quantitative real-time PCR, cDNA was amplified in an ABI PRISM 7500 Sequence Detection System (Applied Biosystems, Life Technologies, Bedford, MA, USA), using SYBR Green Master Mix Reagent (Applied Biosystems, Life Technologies, Foster City, CA, USA). Specific forward and reverse primers $(0,3 \mathrm{M})$ were used (Table 2 ).

Cycling conditions were as follows: step $1,10 \mathrm{~min}$ at $95^{\circ} \mathrm{C}$; step $2,15 \mathrm{~s}$ at $95^{\circ} \mathrm{C}$; step $3,30 \mathrm{~s}$ at $55^{\circ} \mathrm{C}$; step $4,30 \mathrm{~s}$ at $60^{\circ} \mathrm{C}$, repeating 40 times from step 2 to step 4 . Data from the reaction were collected and analyzed by the complementary computer software (Sequence Detection Software, Applied Biosystems, and Version 1.3). The specificity of the signal was confirmed running melting curves. Relative quantification of gene expression was calculated using standard curves and normalized to GADPH in each sample.

To assess the quantitative differences in the cDNA target between samples, the mathematical model of Pfaffl [20] was applied. An expression ratio was determined for each sample by calculating (Etarget) $\Delta \mathrm{Ct}($ target $) /(\mathrm{EGAPDH}) \Delta \mathrm{Ct}(\mathrm{GAPDH})$, where $E$ is the efficiency of the primer set and $\Delta \mathrm{Ct}=\mathrm{Ct}$ (normalization $\mathrm{cDNA})-\mathrm{Ct}$ experimental cDNA). The amplification efficiency of each primer set was calculated from the slope of a standard amplification curve of $\log (\mathrm{ng} \mathrm{cDNA})$ per reaction vs. Ct value $(E=10-(1 /$ slope $))$. Efficiencies of $2 \pm 0.1$ were considered optimal.

\subsection{MTT proliferation assay}

Cells were plated in triplicate in 96-well plates at a density of 2000 cells/well and were stimulated with TGF- $\beta 1(1 \mathrm{ng} / \mathrm{ml})$, progesterone $(1 \mu \mathrm{M})$ or both TGF- $\beta 1(1 \mathrm{ng} / \mathrm{ml})$ plus progesterone $(1 \mu \mathrm{M})$, with or without the progesterone receptor antagonist $\mathrm{Ru}$ 486 (mefiprestone, Sigma, St. Louis, MO, USA, $1 \mu \mathrm{M}$ ) or ALK-5 inhibitor SB431542 (Sigma, St. Louis, MO, USA, $1.3 \mu \mathrm{M}$ ). Ru 486 and SB431542 were added $1 \mathrm{~h}$ before the addition of progesterone or TGF- $\beta 1$. After $24 \mathrm{~h}$, the media was replaced with 3-(4,5-methylthiazol-2-yl)-2,5-diphenyl-tetrazolium bromide (MTT) (Sigma, St. Louis, MO, USA)-containing media $(0.5 \mathrm{mg} / \mathrm{ml})$, incubated at $37{ }^{\circ} \mathrm{C}$ for $45 \mathrm{~min}$, an equal volume of solubilization solution $(10 \%$ SDS) was added, and the plate was incubated at $37^{\circ} \mathrm{C}$ overnight to solubilize formazan crystals. Absorbance was measured at $595 \mathrm{~nm}$ in VERSA MAX tunable microplate reader with the software SOFT max PRO (Version 3.1.1). 
Table 1

Oligonucleotide primers used for PCR amplification of cDNAs obtained alter reverse transcription of TM3 Leydig cells.

\begin{tabular}{|c|c|c|c|c|}
\hline Target (genbank accession number) & Sequence of Primer $\left(5^{\prime} \ldots 3^{\prime}\right)$ & $\operatorname{Tm}(\mathrm{C})$ & Amplified product (bp) & Cycle number \\
\hline TGF- $\beta 1$ (NM_011577) & $\begin{array}{l}\text { F: TCCTGCTTCTCATGGCCA } \\
\text { R: CCTCAGCTGCACTTGTAG }\end{array}$ & 55 & 405 & 35 \\
\hline TGFBRI (NM_009371) & $\begin{array}{l}\text { F: GCGCCAACAACATCAACC } \\
\text { R: GGTACTCCTGCAGGTTGC }\end{array}$ & 56 & 300 & 30 \\
\hline ALK-1 (NM_009612) & $\begin{array}{l}\text { F: CCTTCGGAGGAGCCAGA } \\
\text { R: TATCGGCCCTTTCCCACA }\end{array}$ & 56 & 296 & 30 \\
\hline ALK-5 (NM_004612) & $\begin{array}{l}\text { F: TTGCTGCAATCAGGACCA } \\
\text { R: TAAGGTGGTGCCCTCTGA }\end{array}$ & 56 & 229 & 30 \\
\hline Endoglin (NM_000118) & $\begin{array}{l}\text { F: GCATCCTTCGTGGAGCTA } \\
\text { R: TCATGACCTGATTGCCAC }\end{array}$ & 56 & 300 & 30 \\
\hline$\beta$-Actin (AJ_312092) & $\begin{array}{l}\text { F: GGATGCAGAAGGAGATCA } \\
\text { R: CTAGAAGCATTTGCGGTG }\end{array}$ & 55 & 193 & 26 \\
\hline
\end{tabular}

F: forward; R: reverse.

Table 2

Oligonucleotide primers used for real-time PCR amplification of cDNAs obtained after reverse transcription from TM3 Leydig cells.

\begin{tabular}{ll}
\hline Target (genbank accession number) & Sequence of primer $\left(5^{\prime} \cdots 3^{\prime}\right)$ \\
\hline TGF-1 1 (NM_000660) & F: CCCAGCATCTGCAAAGCTC \\
& R: GTCAATGTACAGCTGCCGCA \\
p15 (NM 007670) & F: TCTGCAGCTGGATCTGGTCC \\
& R:TCCTGAAAGGTAGAGGGCCC \\
PCNA (NM_011045) & F: GCGCAGAGGGTTGGTAGTTG \\
& R: CCCGATTCACGATGCAGAA \\
erg-1 (NM_007913) & F: AAAGTTCACGTCTTGGTGCC \\
& R: GCTCAGCTCAGCCCTCTTCC \\
Endoglin (NM_007932) & F: CTGCCAATGCTGTGCGTGAA \\
& R: ACTTGGCCTACGACTCCAGC \\
KLF-14 (NM_001135093.1) & F: CAGCTCGTCTGGCTCCAA \\
& R: AGGCACTCGGCAGCGAA \\
GADPH (NM_008084) & F: CCAGAACATCATCCCTGCAT \\
& R: GTTCAGCTCTGGGATGACCTT \\
\hline
\end{tabular}

F: forward; R: reverse.

2.5. Scanning of endoglin and 15 gene upstream regions for putative sites

To identify putative progesterone response elements (PRE) consensus regulatory sites, endoglin and 15 gene regulatory regions were analyzed using a bioinformatics-based approach. Up to 1863 and $1500 \mathrm{bp}$ upstream of the translation start codon of endoglin and $\mathrm{p} 15$, respectively, were scanned for significant matches using the MatInspector software [21] from Genomatix (http:// www.genomatix.de).

\subsection{Statistical analysis}

Mean and standard error (SEM) were calculated. Program Graph Pad Prism (version 3.00 for Windows GraphPad software, San Diego California, USA) was used for one-way analysis of variance. Tukey $t$ test was used when differences between more than two groups were compared. A p-value of less than 0.05 was considered significant.

\section{Results}

3.1. TGF- $\beta 1$, TGFBRII, ALK-5, ALK-1 and endoglin gene expression in TM3 Leydig cells

The gene expression of TGF- $\beta 1$, TGFBRII, ALK-5, ALK- 1 and endoglin in TM3 Leydig cells was measured by semi-quantitative
PCR. The amplified cDNA fragments are shown in Fig. 1 confirming the presence of TGF- $\beta 1$ system in this cell type.

\subsection{MTT proliferation assay}

TGF- $\beta 1(1 \mathrm{ng} / \mathrm{ml})$ in the presence of progesterone $(1 \mu \mathrm{M})$ stimulated the number of viable cells indicating a proliferation effect on TM3 Leydig cells. This effect was abolished in the presence of $\mathrm{Ru} 486(1 \mu \mathrm{M})$ which blocks progesterone receptor. The presence of the ALK-5 inhibitor (SB431542) did not modify the proliferative response (Fig. 2).

\subsection{In vitro effect of TGF- $\beta 1$ on $p 15$ and PCNA expression in TM3} Leydig cells

The incubation of TM3 Leydig cells with TGF- $\beta 1(1 \mathrm{ng} / \mathrm{ml})$ induced the expression of p15 at 30 min of incubation (Fig. 3, Panel A). A significant increase in PCNA expression was detected at 10 and 15 min of incubation period (Fig. 3, Panel B).

The incubation of cells with TGF- $\beta 1(1 \mathrm{ng} / \mathrm{ml})$ plus progesterone $(1 \mu \mathrm{M})$ abolished the induction of TGF- $\beta 1$ on $\mathrm{p} 15$ gene expression (Fig. 3, Panel C) but induced a sharp increase in PCNA at 5 and 10 min of incubation period (Fig. 3, Panel D).
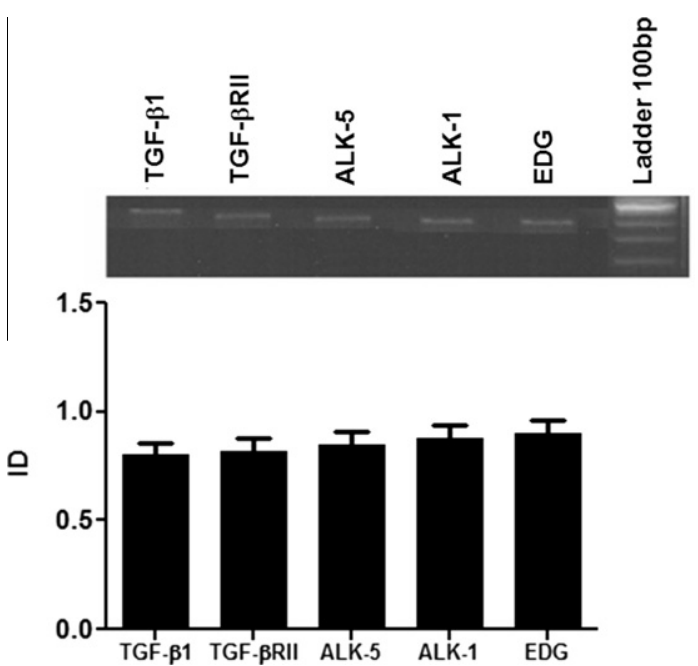

Fig. 1. Gene expression of TGF- $\beta 1$, TGFBRII, ALK-5; ALK-1 and endoglin in TM3 Leydig cells. Results are presented with an arbitrary scale and expressed as the ratios between the expressions of the specific gene and $\beta$-actin (integrated density, ID). Data are plotted as the mean ID \pm SEM. EDG: endoglin. 


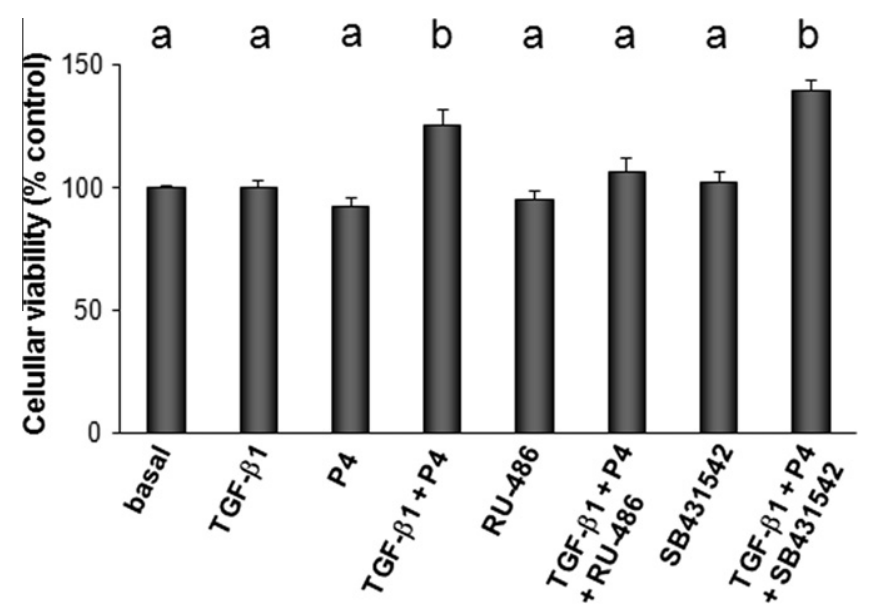

Fig. 2. Proliferation assay of TM 3 cells. The effect of and TGF- $\beta 1(1 \mathrm{mg} / \mathrm{ml})$ and progesterone $\left(\mathrm{P}_{4}, 1 \mu \mathrm{M}\right)$ in the presence or absence of Ru 486 (progesterone inhibitor, $1 \mu \mathrm{M}$ ) or SB 431542 (ALK-5 inhibitor, $1.3 \mu \mathrm{M}$ ) was studied. More details in Material and Methods. Data are plotted as the mean $\pm \operatorname{SEM}(n=6)$. Different letters indicate significant differences $(p<0.05)$.

\subsection{Effect of progesterone on endoglin gene expression}

TM3 Leydig cells were incubated for 1,3 and $6 \mathrm{~h}$ with progesterone $(1 \mu \mathrm{M})$ and endoglin gene expression was evaluated. Progesterone was able to induce a significant increment on endoglin mRNA at 1 and $3 \mathrm{~h}$ of incubation (Fig. 4).

3.5. Putative progesterone response element (PRE) and transcription factors sites on endoglin and 15 gene upstream region

Scanning of 1863 and 1500 bp upstream of the translation start codon of endoglin and $\mathrm{p} 15$, respectively, in the Genomatix
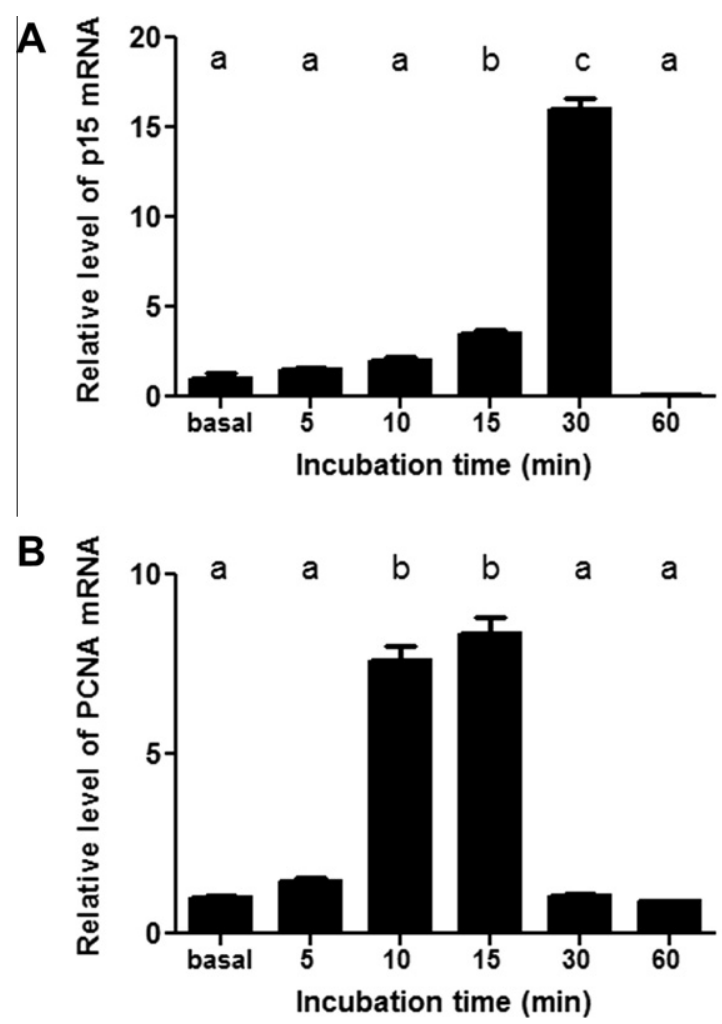

database (http://www.genomatix.de) revealed that no PRE sites were found on the p15 (data not shown) and endoglin gene upstream region, whereas eight KLF family members and one egr-1 sites on the endoglin gene upstream region were detected (Fig. 5).

\subsection{Effect of TGF- $\beta 1$ on egr-1 and KLF14}

TM3 Leydig cells were incubated with TGF- $\beta 1$ in the presence or absence of progesterone and KLF14 and egr-1 gene expression were evaluated. Fig. 6 shows that TGF- $\beta 1(1 \mathrm{ng} / \mathrm{ml})$ induced a small but significant increase in KLF14 gene expression at 5 and $10 \mathrm{~min}$ of incubation (Fig. 6 Panel A) and small and gradual increase in egr-1 mRNA at large periods of incubation (Fig. 6, Panel B). However, a sharp and large increase in KLF14 mRNA and egr-1 were observed when cells were incubated with TGF- $\beta 1$ plus progesterone (Fig. 6, Panels C and D, respectively).

\section{Discussion}

TGF- $\beta 1$ exerts a crucial role in cell proliferation, differentiation and apoptosis. Although the mechanism of TGF- $\beta 1$ signaling has been studied in different experimental conditions, the influence of this cytokine in Leydig cell homeostasis has been scarcely analyzed. The aim of the present work was to gain more insight in the mechanism involved on the effect of TGF- $\beta 1$ on Leydig cell proliferation.

The TGF- $\beta 1$ system has been described in Leydig cells of different species such as mouse, rat, hamster and also human $[6,17,18,22,23]$. In the present study we observed that established TM3 cell line, that was developed from immature non-tumor mouse Leydig cells [19], preserves gene expression of TGF- $\beta 1$, type II and both type I receptors: ALK-1 and ALK-5. Also the gene expression of the co-receptor endoglin was detected. Therefore,
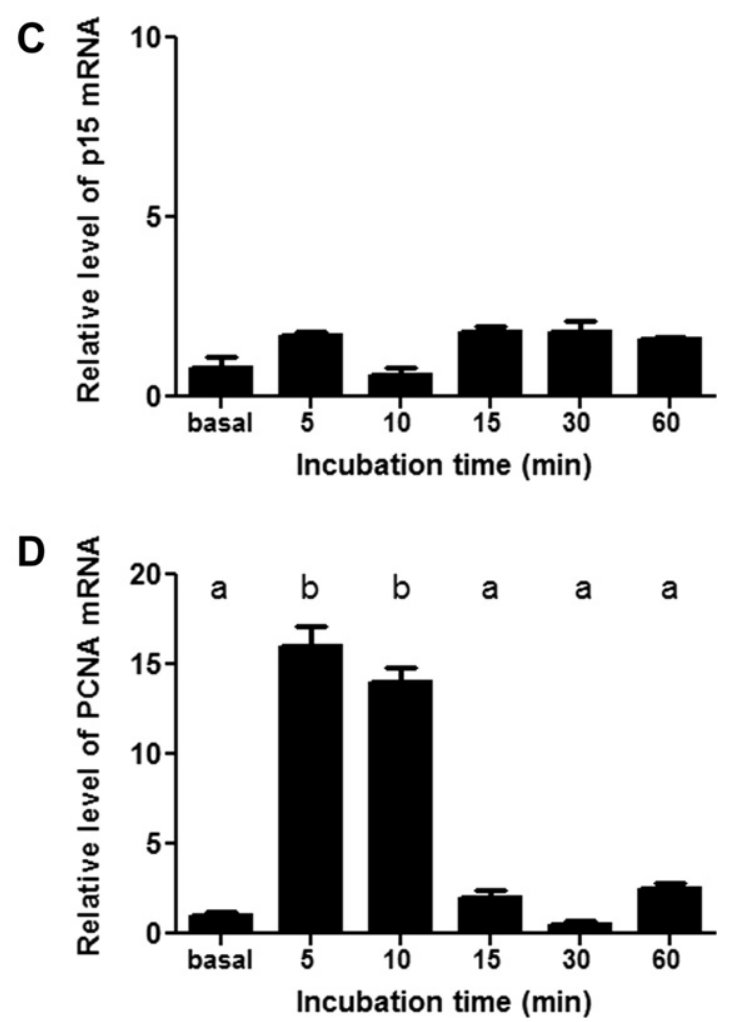

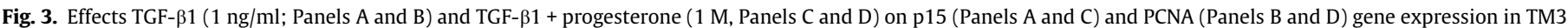

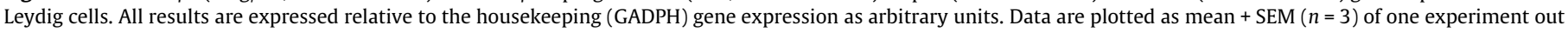
of three. Different letters depict significant differences $(p<0.05)$. 


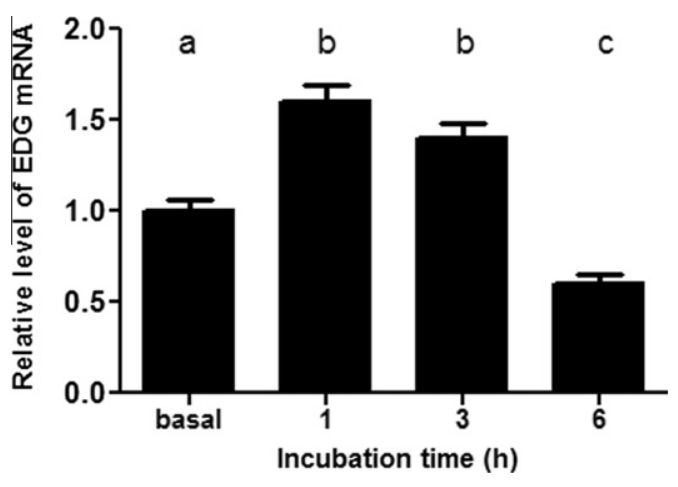

Fig. 4. Effect of progesterone on endoglin (EDG) expression: TM3 Leydig cells were incubated with progesterone $(1 \mu \mathrm{M})$ for 1,3 and $6 \mathrm{~h}$. Different letters indicate significant differences $(p<0.05)$. Results are expressed relative to the housekeeping gene (GADPH) expression as arbitrary units. Data are plotted as the mean \pm SEM of one experiment out of three.

TM3 Leydig cells represent a valuable tool to evaluate the effect of TGF- $\beta 1$ on cell proliferation.

The proliferative response of TGF- $\beta 1$ in the presence of progesterone was confirmed by MTT assay. This effect was not modified by ALK-5 inhibitor; indicating that this type of receptor is not involved in this action. On the other hand, the presence of progesterone receptor inhibitor, Ru 486, abolished this effect showing the participation of this steroid in the proliferative response. These results agree with our previous report in mice, showing that the administration in vivo of TGF- $\beta 1$ plus progesterone directs to the hyperplasia/hypertrophy of Leydig cells [16].

The incubation of TM3 Leydig cells with progesterone induced endoglin gene expression. Lebrin et al. $[9,24]$ have described that this co-receptor is required to induce ALK- 1 signaling efficiently by inhibiting the signaling pathway of ALK-5. However, the analysis of progesterone response elements in endoglin promoter gene region showed negative results.

In the present work, gene expression of p15 was induced by TGF- $\beta 1$ in TM3 Leydig cells. It has been described [25-27] that Smad proteins activate the transcription of $\mathrm{p} 15$, which inhibits CDK-6 and 4 proteins, influencing the cellular cycle and leading to a quiescent state of the cells. Recently, we reported that p15, via erk $1 / 2$ and $\mathrm{p} 38 \mathrm{MAPK}$, might be involved in the functional activity of Leydig cells from regressed and non-regressed hamsters [18]. The presence of progesterone in the incubation media abolishes the stimulatory effect of TGF- $\beta 1$ on p15 expression. At least, to the best of our knowledge, there are no reports concerning the influence of progesterone on p15 expression. The analysis of progesterone response elements in p15 promoter gene region showed negative results.

\section{Endoglin prom.}

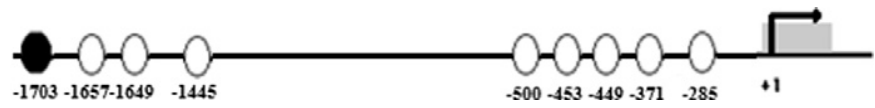

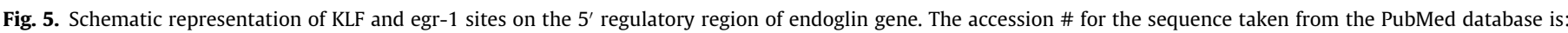

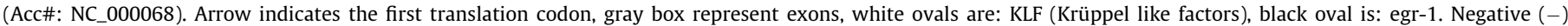
numbers indicate regulatory sites positions relative to the start of translation $(+1)$.
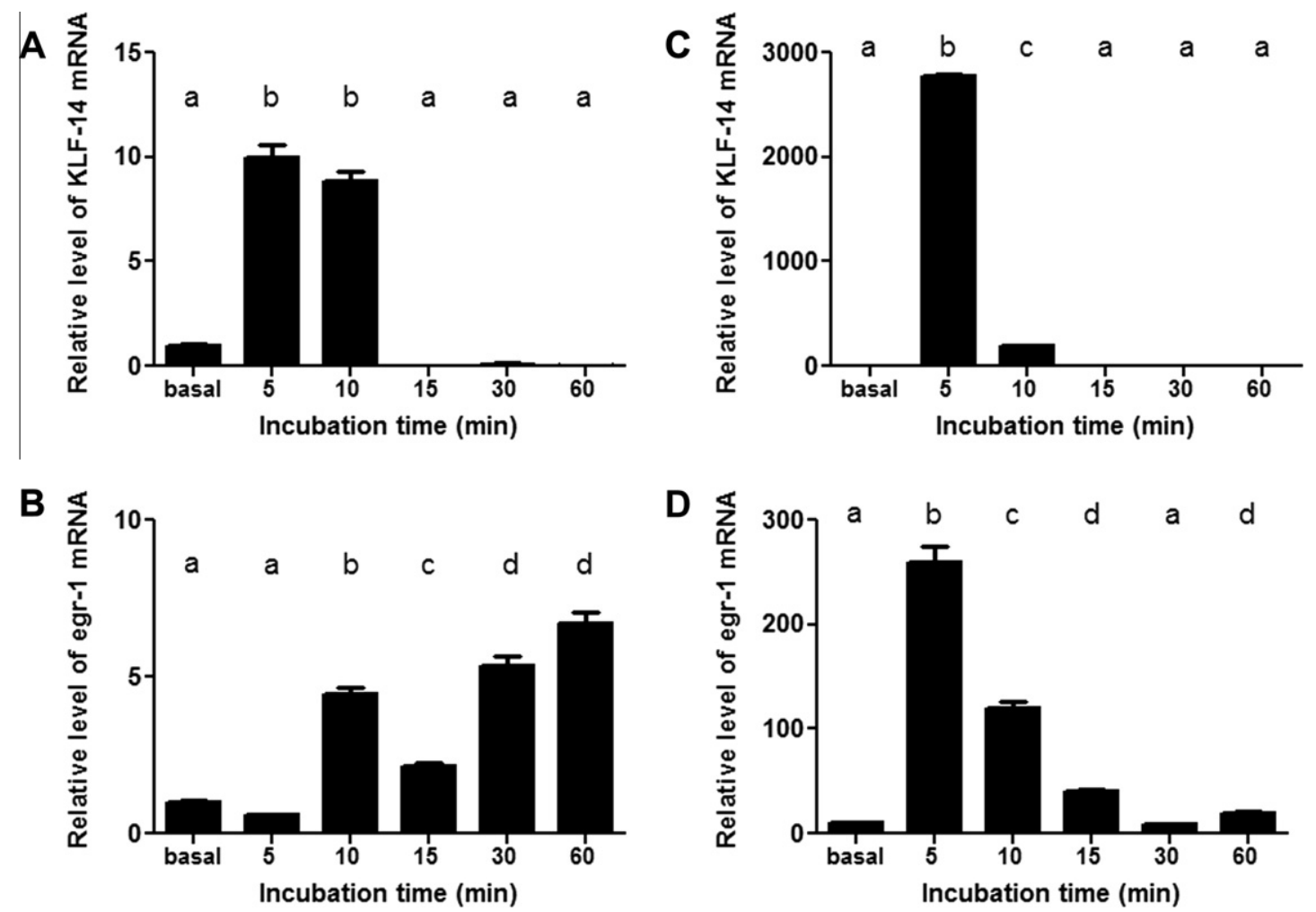

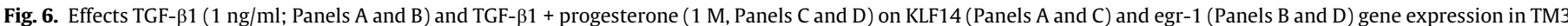

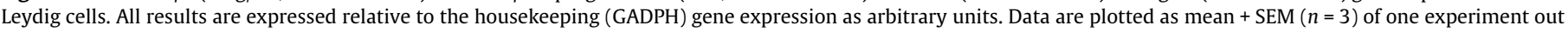
of three. Different letters depict significant differences $(p<0.05)$. 
On the contrary, TGF- $\beta 1$ acting in concert with progesterone leads Leydig cells to a proliferative state revealed by the increase in the gene expression of PCNA. This nuclear protein is synthesized during the early $\mathrm{G} 1$ phase and $\mathrm{S}$ phase of the cellular cycle and acts as a processivity factor for DNA polymerase $\delta$ in eukaryotic cells favoring DNA synthesis [28]. Under our experimental conditions, PCNA is induced more and in a shorter incubation period in cells cultured with TGF- $\beta 1$ plus progesterone than in cells cultured with TGF- $\beta 1$ alone. These results indicate that the presence of progesterone might play a role on the stimulatory response of TGF- $\beta 1$.

The binding of TGF $\beta-1$ to its receptors not only activates the Smad pathway, but also a Smad independent cascade, and transcription factors which might act in concert or independently from each other to regulate gene expression. A large interest focused in the role of non-smads proteins is currently developed. KLF14 is a member of $\mathrm{Sp} / \mathrm{KLF}$ family which acts as transcription factors by binding to GC-enriched sites within target gene promoters. Simmen and Simmen [29] reported that Sp/KLF family interacts with different nuclear proteins in the promoter region on several genes to modify transactivation or transrepression. Particularly, in uterine endometrium, specific members of Sp/KLF family present a cross-talk with ligand-bond progesterone receptors. In this context, Siemmen and Siemmen [29] established that GC-rich sites binding Sp/KLF family members are present within most promoter regions that are progesterone responsive. On the other hand, Owen et al. [30] reported the transcriptional control by progesterone of the cyclin-dependent kinase inhibitor p21 gene by a similar mechanism in a breast cancer cell line. Moreover, Rius et al. [31] have reported that the promoter region of human endoglin presents two GC-rich regions.

Scanning the promoter region of endoglin gene one site for egr1 and eight sites for KLF family members were detected. Early growth response- 1 is an immediate early response gene involved in key cellular processes including the proliferation, differentiation, and apoptosis. Therefore, we evaluated if egr- 1 and KLF14 were involved in the stimulation of Leydig cell proliferation by TGF- $\beta 1$. In our experimental model TGF- $\beta 1$ induces a 7 -fold increase in egr-1, but the presence of progesterone induces this factor 250-fold. Pagel and Deindl [32] reported that egr-1 interconnects a broad variety of cascades upstream and downstream, i.e. egr- 1 is induced by various stimuli and trigger different signaling pathways. In addition, although TGF- $\beta 1$ increased KLF14 10 -fold at $10 \mathrm{~min}$ of incubation, under the simultaneous presence of progesterone this factor was induced by 2800 -fold. These results prompt us to speculate that these transcription factors participate in the intracellular events involved in TGF- $\beta 1$ action in concert with progesterone.

In summary, these results let us to conclude that TGF- $\beta 1$ in the presence of progesterone induces a proliferative response on TM3 Leydig cells. This effect might be due to the induction that progesterone, via activation of KLF14 and egr-1, exerts on endoglin expression, the co-receptor of ALK- 1 , which leads TGF- $\beta 1$ through the signaling pathway of proliferation.

\section{Acknowledgments}

This study was supported by Grants from Consejo Nacional de Investigaciones Científicas y Técnicas (CONICET), Agencia Nacional de Promoción Científica y Técnica (ANPCyT) and Facultad de Medicina-Universidad de Buenos Aires, Argentina.

\section{References}

[1] Ingman WV, Robertson SA. The essential roles of TGFB1 in reproduction. Cytokine Growth Factor Rev 2009;20:233-9.

[2] Ingman WV, Robertson SA. Transforming growth factor-beta1 null mutation causes infertility in male mice associated with testosterone deficiency and sexual dysfunction. Endocrinology 2007;148:4032-43.
[3] Fan YS, Hu YJ, Yang WX. TGF-superfamily: how does it regulate testis development. Mol Biol Rep 2012;39:4727-41.

[4] Gautier C, Levacher C, Saez JM, Habert R. Transforming growth factor beta1 inhibits steroidogenesis in dispersed fetal testicular cells in culture. Mol Cell Endocrinol 1997:131:21-30.

[5] Goddard L, Bouras M, Keramidas M, Hendrick JC, Feige JJ, Benahmed M. Transforming growth factor-beta receptor types I and II in cultured porcine Leydig cells: expression and hormonal regulation. Endocrinology 2000;141: 2068-74

[6] Teerds KJ, Dorrington JH. Localization of transforming growth factor $\beta 1$ and $\beta 2$ during testicular development in the rat. Biol Reprod 1993;48:40-5.

[7] Konrad L, Keilani MM, Laible L, Nottelmann U, Hofmann R. Effects of TGF-betas and a specific antagonist on apoptosis of immature rat male germ cells in vitro. Apoptosis 2006;11:739-48.

[8] Dickson C, Webster DR, Johnson H, Cecilia Millena A, Khan SA. Transforming growth factor-beta effects on morphology of immature rat Leydig cells. Mol Cell Endocrinol 2002;195:65-77.

[9] Lebrin F, Deckers M, Bertolino P, Ten Dijke P. TGF- $\beta$ receptor functions in the endothelium. Cardiov Res 2005;65:599-608.

[10] Feng X-H, Derynck R. Specificity and versatility in TGF- $\beta$ signaling through Smads. Annu Rev Cell Dev Biol 2005;21:659-93.

[11] Moustakas, Heldin CH. Non-Smad TGF-beta signals. J Cell Sci 2005;118(Pt16): 3573-84.

[12] Goumans MJ, Valdimarsdottir G, Itoh S, Lebrin F, Larsson J, Mummery C, et al. Activin receptor-like kinase (ALK) 1 is an antagonistic mediator of lateral TGFbeta/ALK5 signaling. Mol Cell 2003;12:817-28.

[13] Xu P, Liu J, Derynck R. Post-translational regulation of TGF-b receptor and Smad signalling. FEBS Lett 2012;586:1871-84.

[14] Hou X, Arvisais EW, Jiang C, Chen D, Roy SK, Pate JL, et al. Prostaglandin F2 $\alpha$ stimulates the expression and secretion of transforming growth factor B1 via induction of the early growth response 1 gene (EGR 1$)$ in the bovine corpus luteum. Mol Endocrinol 2008;22:403-14.

[15] Truty MJ, Lomberk G, Fernandez-Zapico ME, Urrutia R. Silencing of the transforming growth factor-beta (TGFbeta) receptor II by Krüppel-like factor 14 underscores the importance of a negative feedback mechanism in TGFbeta signalling. J Biol Chem 2009;284:6291-300.

[16] Gonzalez CR, Gonzalez B, Rulli SB, Dos Santos ML, Mattos Jardim Costa G, França LR, et al. TGF- $\beta 1$ system in Leydig cells. Part II: TGF- $\beta 1$ and progesterone, through Smad1/5, are involved in the hyperplasia/hypertrophy of Leydig cells. J Reprod Dev 2010;56:400-4.

[17] Gonzalez CR, Matzkin ME, Frungieri MB, Terradas C, Ponzio R, Puigdomenech E, et al. Expression of the TGF- $\beta 1$ system in human testicular pathologies. Reprod Biol Endocrinol 2010;8:148-59.

[18] Gonzalez CR, Calandra RS, Gonzalez-Calvar SI. Influence of the photoperiod on TGF- $\beta 1$ and p15 expression in hamster Leydig cells. Reprod Biol 2012; 12:201-8.

[19] Mather JP. Establishment and characterization of two distinct mouse testicular epithelial cell lines. Biol Reprod 1980;23:243-52.

[20] Pfaffl MW. A new mathematical model for relative quantification in realtime RT-PCR. Nucleic Acids Res 2001;29:e45.

[21] Quandt K, Frech K, Karas H, Wingender E, Werner T. MatInd and MatInspector: new fast and versatile tools for detection of consensus matches in nucleotide sequence data. Nucleic Acids Res 1995;23:4878-84.

[22] Wagener, Fickel J, Schön J, Fritzenkötter A, Göritz F, Blottner S. Seasonal variation in expression and localization of testicular transforming growth factors TGF- $\beta 1$ and TGF- $\beta 3$ corresponds with spermatogenic activity in roe deer. J Endocrinol 2005;187:205-15.

[23] Gonzalez R, Gonzalez B, Rulli SB, Huhtaniemi I, Calandra RS, Gonzalez-Calvar SI. TGF- $\beta 1$ system in Leydig cells. Part I: Effect of hCG and progesterone. J Reprod Dev 2010;56:389-95.

[24] Lebrin F, Goumans MJ, Jonker L, Carvalho RL, Valdimarsdottir G, Thorikay M et al. Endoglin promotes endothelial cell proliferation and TGF-beta/ALK1 signal transduction. EMBO J 2004;23:4018-28.

[25] Feng X-H, Lin X, Derynck R. Smad2, Smad3 and Smad4 cooperate with Sp1 to induce $\mathrm{p} 15^{\text {Ink } 4 \mathrm{~B}}$ transcription in response to TGF- $\beta$. EMBO J 2000;19:5178-93.

[26] Li X, Zhang YY, Wang Q, Fu SB. Association between endogenous gene expression and growth regulation induced by TGF-beta1 in human gastric cancer cells. World J Gastroenterol 2005;11:61-8.

[27] Li Z, Chen Y, Cao D, Wang Y, Chen G, Zhang S, et al. Glucocorticoid up-regulates transforming growth factor-beta (TGF-beta) type II receptor and enhances TGF-beta signaling in human prostate cancer PC-3 cell. Endocrinology 2006;147:5259-67.

[28] Naryzhny SN. Proliferating cell nuclear antigen: a proteomics view. Cell Mol Life Sci 2008;65:3789-808.

[29] Simmen RC, Simmen FA. Progesterone receptors and Sp/Krüppel-like family members in the uterine endometrium. Front Biosci 2002;7:d1556-65.

[30] Owen GI, Richer JK, Tung L, Takimoto G, Horwitz KB. Progesterone regulates transcription of the p21WAF1 Cyclin dependent kinase inhibitor gene through Sp1 and CBP/p300. J Biol Chem 1998;273:10696-701.

[31] Rius C, Smith JD, Almendro N, Langa C, Botella LM, Marchuk DA, et al. Cloning of the promoter region of human endoglin, the target gene for hereditary hemorrhagic telangiectasia type 1. Blood 1998;92:4677-90.

[32] Pagel JI, Deindl E. Early growth response 1 - a transcription factor in the crossfire of signal transduction cascades. Indian J Biochem Biophys 2011; 48:226-35 